\title{
Kitasatospora putterlickiae sp. nov., isolated from rhizosphere soil, transfer of Streptomyces kifunensis to the genus Kitasatospora as Kitasatospora kifunensis comb. nov., and emended description of Streptomyces aureofaciens Duggar 1948
}

Correspondence

Michael Goodfellow

m.goodfellow@ncl.ac.uk

\author{
Ingrid Groth, ${ }^{1}$ Barbara Schütze, ${ }^{1}$ Theresa Boettcher, ${ }^{2}$ Christian B. Pullen, ${ }^{2}$ \\ Carlos Rodriguez, ${ }^{3}$ Eckhard Leistner ${ }^{2}$ and Michael Goodfellow ${ }^{3}$ \\ ${ }^{1}$ Hans-Knöll-Institut für Naturstoff-Forschung e.V., D-07745 Jena, Germany \\ ${ }^{2}$ Rheinische Friedrich-Wilhelms-Universität, Institut für Pharmazeutische Biologie, D-53115 \\ Bonn, Germany \\ ${ }^{3}$ School of Biology, King George VI Building, University of Newcastle, Newcastle upon Tyne \\ NE1 7RU, UK
}

\begin{abstract}
A polyphasic study was undertaken to establish the taxonomic position of a rhizosphere isolate that had been assigned provisionally to the genus Kitasatospora. The organism, isolate $\mathrm{F} 18-98^{\top}$, was found to have chemical and morphological properties that were consistent with its classification as a Kitasatospora strain. Direct $16 \mathrm{~S}$ rDNA sequence data confirmed the taxonomic position of the strain, following the generation of phylogenetic trees by using three treeing algorithms. The organism formed a 16S rDNA subclade with Kitasatospora azatica and Streptomyces kifunensis, but was distinguished readily from the latter by using a combination of biochemical and physiological properties. Genotypic and phenotypic data show that strain $\mathrm{F} 18-98^{\top}$ should be classified in the genus Kitasatospora as a novel species, for which the name Kitasatospora putterlickiae sp. nov. is proposed; the type strain has been deposited in culture collections as strain F18-98 $8^{\top}$ ( $=$ DSM $44665^{\top}=$ NCIMB $13932^{\top}$ ). It is also proposed that Streptomyces kifunensis should be transferred to the genus Kitasatospora as Kitasatospora kifunensis comb. nov. An emended description of Streptomyces aureofaciens Duggar 1948 is also given.
\end{abstract}

\section{INTRODUCTION}

The genus Kitasatospora (formerly Kitasatosporia) has had a short but turbulent taxonomic history. The taxon was proposed by Ōmura et al. (1982), subsequently subsumed within the genus Streptomyces (Wellington et al., 1992; Ochi \& Hiranuma, 1994), re-established by Zhang et al. (1997) and thereafter recognized in subsequent studies (Chung et al., 1999; Tajima et al., 2001). The genus belongs to the family Streptomycetaceae, together with the genera Streptacidiphilus and Streptomyces (Kim et al., 2003). Kitasatosporae are aerobic, Gram-positive, chemo-organotrophic actinomycetes

\footnotetext{
Abbreviations: $\mathrm{A}_{2} \mathrm{pm}$, diaminopimelic acid; ISP, International Streptomyces Project.

The GenBank/EMBL/DDBJ accession numbers for the $16 \mathrm{~S}$ rDNA sequences of Kitasatospora putterlickiae $\mathrm{F} 18-98^{\top}$ and Streptomyces aureofaciens IMET 43577 ${ }^{\top}$ are AY189976 and AY289116, respectively. The accession number for the 16S-23S rDNA spacer region of Kitasatospora putterlickiae is AY189977.
}

that form an extensively branched substrate mycelium and aerial hyphae that differentiate into long chains of spores and typically produce whole-organism hydrolysates that are rich in galactose and LL- and meso-diaminopimelic acid $\left(\mathrm{A}_{2} \mathrm{pm}\right)$. Aerial spores on solid culture and submerged spores in liquid culture contain LL- $\mathrm{A}_{2} \mathrm{pm}$, whereas mycelium grown under both culture conditions mainly contains meso$\mathrm{A}_{2} \mathrm{pm}$ (Ōmura et al., 1981, 1982; Takahashi et al., 1984).

The eleven species of Kitasatospora that have validly published names at the time of writing are Kitasatospora azatica (Nakagaito et al. 1993) Zhang et al. 1997, Kitasatospora cheerisanensis Chung et al. 1999, Kitasatospora cineracea Tajima et al. 2001, Kitasatospora cochleata (Nakagaito et al. 1993) Zhang et al. 1997, Kitasatospora cystarginea Kusakabe and Isono 1992, Kitasatospora griseola Takahashi et al. 1985, Kitasatospora mediocidica Labeda 1988, Kitasatospora niigatensis Tajima et al. 2001, Kitasatospora paracochleata (Nakagaito et al. 1993) Zhang et al. 1997, Kitasatospora 
phosalacinea Takahashi et al. 1985 and Kitasatospora setae Ōmura et al. 1983 [species name corrected by Ōmura et al. (1985)], which is the type species of the genus. The taxonomic integrity of these species, which form a distinct phyletic branch in the 16S rDNA tree, is supported by a wealth of genotypic and phenotypic data. The current classification of the genus provides a sound framework for the description of additional Kitasatospora species, some of which can be expected to include strains of industrial significance.

The taxonomic position of Streptomyces aureofaciens Duggar 1948 needs to be clarified. The organism was included in the International Streptomyces Project (ISP) (Shirling \& Gottlieb, 1968) as a bone fide member of the genus Streptomyces and was considered subsequently to be an agent of potato scab (Goyer et al., 1996; Kreuze et al., 1999; Bouchek-Mechiche et al., 2000). However, Kreuze et al. (1999) suggested that S. aureofaciens NRRL $2209^{\mathrm{T}}$ was misclassified in the genus Streptomyces and probably belonged to the genus Kitasatospora, a view that was based mainly on $16 \mathrm{~S}$ rDNA sequence data. However, in a numerical taxonomic survey based on the simple matching coefficient and the UPGMA algorithm, strain NRRL $2209^{\mathrm{T}}$ was recovered in an aggregate cluster equated with the genus Streptomyces (Williams et al., 1983).

The primary aim of the present investigation was to determine the taxonomic position of an organism presumptively assigned to the genus Kitasatospora, strain F18-98 ${ }^{\mathrm{T}}$, which had been isolated from the rhizosphere of a Putterlickia verrucosa plant in South Africa during an investigation of endophytic actinomycetes associated with the plant family Celastraceae (Pullen et al., 2002, 2003). Data from polyphasic taxonomic study of the organism showed that it should be recognized as a novel species of Kitasatospora, for which the name Kitasatospora putterlickiae sp. nov. is proposed. Studies were also carried out to clarify the taxonomic positions of the type strains of $S$. aureofaciens and Streptomyces kifunensis.

\section{METHODS}

Bacterial strains and culture conditions. Strain $\mathrm{F} 18-98^{\mathrm{T}}$ was isolated from the rhizosphere of plant ' $\mathrm{F}$ ', a Putterlickia verrucosa (E. Meyer ex Sonder) Szyszyl plant that grows in South Africa; the location and biotope of this plant were described by Pullen et al. (2003). The organism was isolated following a procedure modified slightly from that described by Hunter-Cevera et al. (1986): an airdried soil sample $(1 \mathrm{~g})$ that contained hairy roots of the plant was pre-treated at $95^{\circ} \mathrm{C}$ in a dry oven for $1 \mathrm{~h}$, suspended in sterile water $(2 \mathrm{ml})$ and a $0 \cdot 1 \mathrm{ml}$ aliquot was spread over a yeast extract/malt agar plate (ISP medium 2; Shirling \& Gottlieb, 1966) supplemented with propiconazol (10 p.p.m.). The inoculated plate was incubated at $28^{\circ} \mathrm{C}$ for 3-4 days, while representative actinomycete colonies were grown under the same conditions on ISP 2 agar that lacked propiconazol. Stock cultures of the selected isolate (strain $\mathrm{F} 18-98^{\mathrm{T}}$ ) in liquid organic medium 79 (Prauser et al., 1987) supplemented with $5 \%$ DMSO were maintained in either the vapour phase of liquid nitrogen or at $-80^{\circ} \mathrm{C}$ by adding glycerol medium $(1: 1)$ that consisted of: $\mathrm{K}_{2} \mathrm{HPO}_{4}, 1.26 \% ; \mathrm{KH}_{2} \mathrm{PO}_{4}, 0.36 \% ; \mathrm{MgSO}_{4}, 0.01 \%$; sodium citrate, $0 \cdot 09 \%$; $\left(\mathrm{NH}_{4}\right)_{2} \mathrm{SO}_{4}, 0 \cdot 18 \%$; and glycerol, $8 \cdot 8 \%$.
Bacterial growth for chemotaxonomic and morphological studies on all three strains was prepared by cultivating them in liquid organic medium 79 (Prauser et al., 1987), Bacto tryptic soy broth (SigmaAldrich) and on ISP media 2, 3, 4 and 5 (Difco; Shirling \& Gottlieb, $1966)$ at $28^{\circ} \mathrm{C}$ for $10-15$ days. Physiological tests were carried out on carbon utilization agar (ISP medium 9) or on ISP medium 2. Susceptibility to polyvalent Streptomyces phages was tested by dropping high-titre suspensions of phage S7 (DSM 49153) onto agar plates seeded with spores of strain F18- $98^{\mathrm{T}}$ held in a soft agar layer. Phage S7 was propagated in host strain Streptomyces olivaceus DSM 41536 by growing the latter in liquid organic medium 79 for $24 \mathrm{~h}$ at $28^{\circ} \mathrm{C}$. $K$. azatica DSM $41650^{\mathrm{T}}$ was included in these studies for comparative purposes.

Morphological and physiological characteristics. Morphological characteristics were observed by light and electron microscopy. Dimensions of spores were measured by using an Axioskop 2 microscope equipped with image analysing AxioVision 2.05 software (both from Zeiss). Samples for electron microscopy were prepared following Shirling \& Gottlieb (1966) and observed by using a CEM 902A electron microscope (Zeiss) at an acceleration voltage of $80 \mathrm{kV}$. Culture characteristics, production of melanoid pigments and utilization of carbon sources were determined according to methods described by Shirling \& Gottlieb (1966). pH range for growth was established by using liquid ISP medium 2, adjusted to $\mathrm{pH}$ values between 4 and 10 with either $1 \mathrm{M} \mathrm{HCl}$ or $20 \%$ (w/v) $\mathrm{Na}_{2} \mathrm{CO}_{3}$ solution and incubated at $28^{\circ} \mathrm{C}$ for up to 10 days. Temperature growth range and tolerance to $\mathrm{NaCl}$ were recorded on ISP 2 agar plates that were incubated at $28{ }^{\circ} \mathrm{C}$ for up to 21 days. Liquefaction of gelatin, hydrogen sulfide production and nitrate reduction were examined as described by Lányi (1987). Casein degradation, hydrolysis of potato starch and peptonization of milk were determined according to Cowan \& Steel (1965). Enzymic activities of 48-h-old cultures grown in liquid organic medium 79 were examined by using API ZYM galleries (bioMérieux), following the manufacturer's instructions. Susceptibility to antibiotics was tested by placing antibiotic discs (Difco) on organic medium 79 agar plates that were seeded with suspensions of the tested strains that had been grown in a soft agar layer for $1-2$ days at $28^{\circ} \mathrm{C}$. Additionally, nalidixic acid and novobiocin were added at different concentrations to ISP 2 agar plates, which were then inoculated with spores of the tested strains.

Chemotaxonomic characteristics. Isomers of $\mathrm{A}_{2} \mathrm{pm}$ in wholeorganism hydrolysates were analysed according to the method of Hasegawa et al. (1983) by using the solvent system of Rhuland et al. (1955) and paper chromatography. Whole-organism sugars were determined by the method of Becker et al. (1965) and by GC according to Saddler et al. (1991). The colorimetric method of Uchida \& Aida (1984) was used to determine muramic acid type. Menaquinones were extracted as described by Collins et al. (1977) and analysed by using an HPLC instrument (Shimadzu), which consisted of a model LC-9A solvent delivery module, an on-line degasser (Knauer), a model CTO-6A column oven, a model SIL-9A automatic sample injector and a model SPD-6AV UV-VIS spectrophotometric detector and was fitted with an EC 250/4 Nucleosil 120-5 C18 column (Macherey-Nagel). Fatty acid profiles were analysed by using the MIDI system (Agilent) and cultures grown in Bacto tryptic soy broth for $48 \mathrm{~h}$ at $28^{\circ} \mathrm{C}$; mycolic acids were sought by using the TLC procedure described by Minnikin et al. (1975). Polar lipids, extracted by the method of Minnikin et al. (1979), were identified by two-dimensional TLC and spraying with specific reagents (Collins \& Jones, 1980).

Small-subunit rDNA sequencing. $16 \mathrm{~S}$ rDNA amplification and sequencing of strain $\mathrm{F} 18-98^{\mathrm{T}}$ were carried out as described by Edwards et al. (1989). The resultant sequence was aligned manually with corresponding almost-complete sequences of representatives of most actinomycete genera and then with almost-complete sequences 
of the type strains of Kitasatospora, Streptacidiphilus and representative Streptomyces species; in each case, reference sequences were retrieved from DDBJ/EMBL/GenBank. Evolutionary trees were inferred by using the least-squares (Fitch \& Margoliash, 1967), maximumlikelihood (Felsenstein, 1981) and neighbour-joining (Saitou \& Nei, 1987) algorithms, which form part of the PHYLIP 3.5c package (Felsenstein, 1993); evolutionary distance matrices for the neighbourjoining method were generated as described by Jukes \& Cantor (1969). The resultant unrooted tree topologies were evaluated by carrying out bootstrap analyses (Felsenstein, 1985) of the neighbourjoining data, based on 1000 resamplings, by using the SEQBOOT and CONSENSE programs from PHYLIP 3.5c (Felsenstein, 1993).

Similarly, 16S rDNA amplification and sequencing of S. aureofaciens IMET $43577^{\mathrm{T}}$ was carried out as described by Kim et al. (1998). The resultant sequence was aligned manually with corresponding almostcomplete sequences of available type strains of Streptomyces species that were retrieved from DDBJ/EMBL/GenBank by using the AL16S program (Chun, 1995). Evolutionary trees were inferred by using the neighbour-joining algorithm (Saitou \& Nei, 1987). Robustness of the tree was evaluated by performing bootstrap analysis, as described above. A partial $16 \mathrm{~S}$ rDNA nucleotide sequence $(120 \mathrm{nt})$ of the tested strain, based on the variable $\gamma$-region, was compared with the corresponding nucleotide sequences of Streptomyces strains retrieved from GenBank. A phylogenetic tree based on these sequences was generated by using the neighbour-joining algorithm (Saitou \& Nei, 1987).

Cloning and sequencing of the 16S-23S rDNA spacer region. Cloning and sequencing of PCR-amplified spacer fragments of the three strains were carried out as described by Wang et al. (1996a, b).

\section{RESULTS AND DISCUSSION}

Phenotypic and phylogenetic characteristics of strain F18-98 ${ }^{\mathrm{T}}$ and S. kifunensis DSM $41654^{\mathrm{T}}$ are consistent with their classification in the genus Kitasatospora (Ōmura et al., 1982; Zhang et al., 1997).

An almost-complete $16 \mathrm{~S}$ rDNA sequence (1553 nt) was determined for strain F18-98 ${ }^{\mathrm{T}}$. Preliminary phylogenetic analysis placed the strain within the evolutionary radiation encompassed by the genus Kitasatospora (data not shown). When the sequence of strain F18-98 ${ }^{\mathrm{T}}$ was compared with corresponding $16 \mathrm{~S}$ rDNA sequences of the type strains of Kitasatospora and Streptacidiphilus species and representatives of the genus Streptomyces, the organism formed a monophyletic clade with $K$. azatica NBRC $13803^{\mathrm{T}}$ and S. kifunensis NBRC $15206^{\mathrm{T}}$ (Fig. 1). This relationship was evident in evolutionary trees based on three different treeing algorithms and was supported by a bootstrap value of $84 \%$. Nucleotide sequence similarity values between the isolate and the kitasatosporae ranged from $96.4 \%$ (with K. niigatensis) to $98.6 \%$ (with S. kifunensis), values that correspond to 51 and 20 nucleotide differences in 1430 nucleotide positions, respectively. The 16S-23S rDNA spacer sequence data showed that the tested strain contained the nine nucleotide sequence characteristics of the genus Kitasatospora (Zhang et al., 1997).

Strain F18-98 ${ }^{\mathrm{T}}$ formed an extensively branched, nonfragmenting substrate mycelium that was seen to carry aerial hyphae and spores within 3 days. Smooth-surfaced, cylindrical spores were borne in long, straight to flexuous spore-chains. Culture characteristics of the strain are shown in Table 1. It was evident that aerial spore-mass colour changed from pale brown to grey as colonies aged. In liquid culture, spores germinated to form long, sparsely branched hyphae that fragmented subsequently into irregular segments and spore-like bodies.

Whole-organism hydrolysates of strain F18- $98^{\mathrm{T}}$ contained predominant amounts of $\mathrm{LL}-\mathrm{A}_{2} \mathrm{Pm}$ and relatively small amounts of the corresponding meso-isomer. The organism was also characterized by the presence of $\mathrm{N}$-acetylated muramic acid, the sugars galactose, mannose and rhamnose,

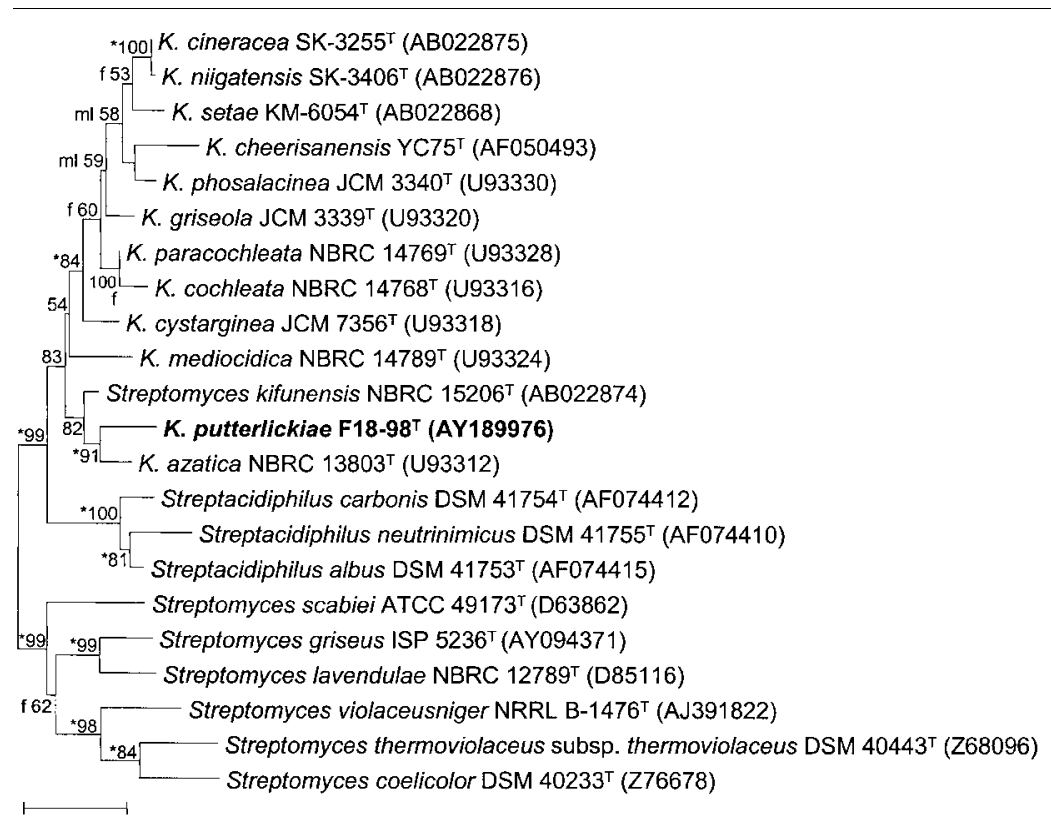

Fig. 1. Unrooted neighbour-joining tree (Saitou $\&$ Nei, 1987) based on nearly complete $16 \mathrm{~S}$ rDNA sequences, showing the position of strain $\mathrm{F} 18-98^{\top}$ in the Kitasatospora tree. Asterisks indicate branches that were also recovered by using both the least-squares (Fitch \& Margoliash, 1967) and maximumlikelihood (Felsenstein, 1981) algorithms; $f$ and $\mathrm{ml}$ indicate branches formed by using the least-squares or maximum-likelihood treeing methods, respectively. Numbers at nodes are bootstrap values (\%) based on 1000 resampled datasets; only values $>50 \%$ are given. Bar, 0.1 nucleotide substitutions per nucleotide position. 
Table 1. Culture characteristics of strain $\mathrm{F} 18-98^{\top}$

\begin{tabular}{|lcll|}
\hline Medium $^{\star}$ & Colour of aerial spore-mass & Reverse colour & Soluble pigment \\
\hline Yeast extract/malt extract agar (ISP 2) & Dark grey & Dark brown & Dark brown \\
Oatmeal agar (ISP 3) & Grey & Yellowish brown & Brown \\
Inorganic salts/starch agar (ISP 4) & Dark grey & Beige, pale grey & None \\
Glycerol/asparagine agar (ISP 5) & Dark grey & Dark brown & None \\
\hline
\end{tabular}

${ }^{\star}$ Good growth occurred on all media.

major amounts of diphosphatidylglycerol, phosphatidylethanolamine, phosphatidylglycerol, phosphatidylinositol and phosphatidylinositol mannosides [phospholipid type 2 sensu Lechevalier et al. (1977)] and a menaquinone profile that consisted of di-, tetra- and hexahydrogenated components with nine isoprene units and tetrahydrogenated components with 10 and 11 isoprene units (peak area ratios: $14,23,24,14$ and 10, respectively). The cellular fatty acid profile was characterized by major proportions of 14-methylpentadecanoic acid (iso- $\mathrm{C}_{16: 0}, 36 \cdot 5 \%$ ), hexadecanoic acid $\left(\mathrm{C}_{16: 0}, 9 \cdot 2 \%\right)$, hexadecenoic acid $\left(\mathrm{C}_{16: 1}, 8 \cdot 9 \%\right)$ and 13-methyltetradecanoic acid (iso- $\mathrm{C}_{15: 0}, 8 \cdot 6 \%$ ); mycolic acids were not detected.

Chemotaxonomic and morphological data, together with the results of molecular systematic studies, show that strain $\mathrm{F} 18-98^{\mathrm{T}}$ is a bona fide member of the genus Kitasatospora. It is also interesting that the strain is resistant to polyvalent Streptomyces phage S7, which is known to lyse 121 of 151 Streptomyces strains that represent 90 species (H. Prauser, personal communication). It is clear from Table 2 that strain $\mathrm{F} 18-98^{\mathrm{T}}$ can be distinguished readily from its two closest phylogenetic neighbours by using a combination of biochemical and physiological tests. All three of these strains were sensitive to low concentrations of novobiocin $\left(5 \mu \mathrm{g} \mathrm{ml}^{-1}\right)$ and hence cannot be expected to grow on the novobiocin-containing agar medium used by Tajima et al. (2001) to isolate strains of K. cineracea and K. niigatensis.

It can be concluded from the genotypic and phenotypic data that strain $\mathrm{F} 18-98^{\mathrm{T}}$ forms a novel Kitasatospora species. It is, therefore, proposed that this organism should be classified as Kitasatospora putterlickiae sp. nov.

'Kitasatospora kifunense' was proposed by Iwami et al. (1987) and later transferred to the genus Streptomyces as S. kifunensis Nakagaito et al. 1993 with NBRC $15206^{\mathrm{T}}$ as the type strain. The results of the present investigation are in line with those from previous studies (Nakagaito et al., 1992a, b; Zhang et al., 1997) in showing that the type strain of $S$. kifunensis belongs to the genus Kitasatospora. In the present study, S. kifunensis DSM $41654^{\mathrm{T}}$ was shown to contain LL- and meso- $\mathrm{A}_{2} \mathrm{pm}$ in whole-organism hydrolysates, $N$-acetylated muramic acid, major amounts of diphosphatidylglycerol, phosphatidylethanolamine, phosphatidylglycerol, phosphatidylinositol and phosphatidylinositol mannosides, hexahydrogenated menaquinone with
Table 2. Phenotypic properties that separate strain F18$98^{\top}$ from related Kitasatospora species

Taxa: 1, strain F18-98 ${ }^{\mathrm{T}} ; 2$, K. azatica DSM $41650^{\mathrm{T}} ; 3$, K. kifunensis DSM $41654^{\mathrm{T}}$. + , Positive; $+{ }^{\mathrm{d}}$, delayed positive; - , negative; $\mathrm{W}$, weakly expressed.

\begin{tabular}{|c|c|c|c|}
\hline Characteristic & 1 & 2 & 3 \\
\hline Formation of melanoid pigments & + & - & + \\
\hline \multicolumn{4}{|l|}{ Biochemical tests: } \\
\hline Gelatin liquefaction & + & $+{ }^{\mathrm{d}}$ & - \\
\hline Hydrolysis of potato starch & - & + & + \\
\hline Nitrate reduction & + & + & - \\
\hline \multicolumn{4}{|l|}{ Enzyme assay (API ZYM): } \\
\hline$\alpha$-Glucosidase & - & $\mathrm{w}$ & + \\
\hline$\beta$-Glucosidase & + & - & - \\
\hline Naphthol-AS-BI-phosphohydrolase & - & + & + \\
\hline \multicolumn{4}{|l|}{ Growth on sole carbon sources: } \\
\hline $\mathrm{L}(+)$-Arabinose & - & + & + \\
\hline $\mathrm{D}(+)$-Fructose & $\mathrm{W}$ & + & - \\
\hline $\mathrm{D}(+)$-Mannitol & - & - & + \\
\hline $\mathrm{D}(-)$-Sucrose & $\mathrm{W}$ & + & + \\
\hline $\mathrm{D}(+)$-Xylose & - & + & + \\
\hline \multicolumn{4}{|l|}{ Growth in the presence of $\mathrm{NaCl}(\%)$ : } \\
\hline 2 & + & - & + \\
\hline $2 \cdot 5$ & + & - & + \\
\hline 3 & + & - & - \\
\hline \multicolumn{4}{|l|}{$\mathrm{pH}$ for growth: } \\
\hline 9 & + & - & $+^{*}$ \\
\hline $9 \cdot 5$ & + & - & - \\
\hline Growth at $35^{\circ} \mathrm{C}$ & + & $\mathrm{w}$ & - \\
\hline \multicolumn{4}{|l|}{ Resistance to antibiotics: } \\
\hline Penicillin G (10 IU) & - & - & + \\
\hline Polymyxin B (300 IU) & $\mathrm{W}$ & - & + \\
\hline Sulfonamide $(200 \mu \mathrm{g})$ & + & - & - \\
\hline
\end{tabular}

${ }^{\star}$ Growth after 6 days.

nine isoprene units as the predominant isoprenologue, galactose, glucose, mannose and ribose as whole-organism sugars and fatty acids rich in iso- and anteiso-branched components. In addition, the 16S-23S rDNA spacer region contained the nine nucleotide sequence characteristics of the genus Kitasatospora (Zhang et al., 1997). The organism was also resistant to polyvalent Streptomyces phage S7. It is 
evident from Fig. 1 that the organism forms a 16S rDNA subclade with the type strains of $K$. azatica and $K$. putterlickiae, but can be distinguished readily from the latter by using a combination of phenotypic properties (Table 2). It is therefore clear that S. kifunensis Nakagaito et al. 1993 should be transferred to the genus Kitasatospora as Kitasatospora kifunensis comb. nov.

The chemical and morphological properties of S. aureofaciens IMET $43577^{\mathrm{T}}$ recorded in the present study are consistent with its classification in the genus Streptomyces (Williams et al., 1989; Manfio et al., 1995). The organism forms an extensively branched substrate mycelium and aerial hyphae that differentiate into chains of spores and contains LL- $\mathrm{A}_{2} \mathrm{pm}$ in the cell-wall peptidoglycan, $\mathrm{N}$-acetylated muramic acid, complex mixtures of iso- and anteiso-branched fatty acids and tetra-, hexa- and octahydrogenated menaquinones as the predominant isoprenologues. The strain was also sensitive to polyvalent Streptomyces phage S7 and has a 16S-23S rDNA spacer region sequence that lacks the nucleotide signature of Kitasatospora strains (Zhang et al., 1997). Retention of the organism in the genus Streptomyces is also supported by the present $16 \mathrm{~S}$ rDNA nucleotide sequence data.

Comparison of the almost-complete 16S rDNA nucleotide sequence of S. aureofaciens IMET $43577^{\mathrm{T}}$ with corresponding sequences of marker strains of the genera Kitasatospora, Streptacidiphilus and Streptomyces clearly show that it forms a distinct phyletic line within the evolutionary radiation occupied by the genus Streptomyces (data not shown). The organism was related most closely to the type strains of Streptomyces ambofaciens, Streptomyces paradoxus and Streptomyces tendae, although these relationships were not supported by high bootstrap values. Strain IMET $43577^{\mathrm{T}}$ shared 16S rDNA nucleotide similarities with the three type strains of $98.9,98.9$ and $98.8 \%$, respectively; values that corresponded to 16, 15 and 17 nucleotide differences at 1448 sites. $16 \mathrm{~S}$ rDNA similarity values much higher than these figures have been recorded between type strains of several Streptomyces species that are known to have relatively low DNA-DNA relatedness values (Sembiring et al., 2000; Kim \& Goodfellow, 2002), i.e. below the $80 \%$ cut-off point recommended for the recognition of genomic species of Streptomyces (Labeda \& Lyons, 1992; Labeda, 1993, 1998). The clear separation of S. aureofaciens IMET $43577^{\mathrm{T}}$ from representatives of Streptomyces species with validly published names is underpinned by the results from the $120 \mathrm{nt}$ $16 \mathrm{~S}$ rDNA sequence analysis (data not shown). The present $16 \mathrm{~S}$ rDNA nucleotide sequence of the type strain of $S$. aureofaciens differed from the earlier one that was deposited in GenBank under accession no. Y15504 by 89 nucleotide differences at 1438 sites.

\section{Description of Kitasatospora putterlickiae sp. nov.}

Kitasatospora putterlickiae (put.ter.lic'ki.ae. N.L. gen. n. putterlickiae of the plant genus Putterlickia).
Aerobic, Gram-positive, non-acid-fast actinomycete that produces a dark-brown substrate mycelium and a dark-grey aerial spore-mass on glycerol/asparagine and yeast extract/ malt extract agars. Brown soluble pigments are formed on oatmeal and yeast extract/malt extract agars and melanoid pigments are formed on peptone/yeast extract/iron and tyrosine agars. Spore-chains are straight to flexuous (rectiflexibiles), with 20 or more cylindrical, smoothsurfaced spores $(1.6-2.5 \times 1.0-1.5 \mu \mathrm{m})$ per chain. Submerged spores are formed in liquid culture. Temperature range for growth is $10-37^{\circ} \mathrm{C}$ (optimum is between 28 and $32^{\circ} \mathrm{C}$ ); growth does not occur at either 6 or $40^{\circ} \mathrm{C}$. Good growth occurs at $\mathrm{pH} 5-9$; growth does not occur at $\mathrm{pH} 4.5$ or above $\mathrm{pH} 9 \cdot 5$. Nitrate is reduced to nitrite, gelatin is liquefied, milk is peptonized, casein is degraded and $\mathrm{H}_{2} \mathrm{~S}$ is weakly produced. Starch is not hydrolysed. Alkaline phosphatase, esterase $(\mathrm{C} 4)$, esterase lipase (C8), leucine arylamidase, acid phosphatase, $\beta$-galactosidase and $\beta$-glucosidase are produced, but $N$-acetyl- $\beta$-glucosamidase, $\alpha$-chymotrypsin, cystine arylamidase, $\alpha$-fucosidase, $\alpha$-galactosidase, $\alpha$ glucosidase, $\beta$-glucuronidase, lipase (C14), $\alpha$-mannosidase, naphthol-AS-BI-phosphohydrolase, trypsin and valine arylamidase are not. $\mathrm{D}(+)$-Fructose (weak), $\mathrm{D}(+)$-glucose and $\mathrm{D}(-)$-sucrose (weak) are used as sole sources of carbon for energy and growth, but $\mathrm{L}(+)$-arabinose, cellulose, i-inositol, $\mathrm{D}(-)$-mannitol, $\mathrm{D}(+)$-raffinose, $\mathrm{L}(+)$-rhamnose and $\mathrm{D}(+)$-xylose are not. Growth is inhibited by ampicillin $\left(10 \mu \mathrm{g} \mathrm{ml}^{-1}\right)$, chloramphenicol $\left(30 \mu \mathrm{g} \mathrm{ml}^{-1}\right)$, ciprofloxacin $\left(5 \mu \mathrm{g} \mathrm{ml}^{-1}\right)$, imipenem $\left(10 \mu \mathrm{g} \mathrm{ml}^{-1}\right)$, kanamycin sulfate $\left(30 \mu \mathrm{g} \mathrm{ml}^{-1}\right)$, methicillin $\left(5 \mu \mathrm{g} \mathrm{ml}^{-1}\right.$, weak), novobiocin $\left(2.5 \mu \mathrm{g} \mathrm{ml}^{-1}\right)$, oxytetracycline hydrochloride $\left(30 \mu \mathrm{g} \mathrm{ml}^{-1}\right)$, penicillin $\mathrm{G}(10 \mathrm{IU})$, polymyxin B (300 IU, weak), rifampicin $\left(30 \mu \mathrm{g} \mathrm{ml}^{-1}\right)$, streptomycin sulfate $\left(10 \mu \mathrm{g} \mathrm{ml}^{-1}\right)$, vancomycin hydrochloride $\left(30 \mu \mathrm{g} \mathrm{m}^{-1}\right)$ and nalidixic acid $\left(50 \mu \mathrm{g} \mathrm{ml}^{-1}\right)$, but not by lincomycin hydrochloride $\left(2 \mu \mathrm{g} \mathrm{ml}^{-1}\right)$, norfloxacin $\left(10 \mu \mathrm{g} \mathrm{ml}^{-1}\right)$ or sulfonamide $\left(200 \mu \mathrm{g} \mathrm{ml}^{-1}\right) . \mathrm{NaCl}$ is tolerated up to a concentration of $3.5 \%(\mathrm{w} / \mathrm{v})$. Resistance is shown to polyvalent Streptomyces phage S7. Whole-cell chemistry reveals the presence of both meso- and LL- $\mathrm{A}_{2} \mathrm{pm}$; the muramic acid moiety is $\mathrm{N}$-acetylated. Whole-organism hydrolysates contain galactose, madurose, mannose and rhamnose and the major polar lipids are diphosphatidylglycerol, phosphatidylethanolamine, phosphatidylglycerol, phosphatidylinositol and phosphatidylinositol mannosides. Predominant fatty acids are $\mathrm{C}_{16: 0}, \mathrm{C}_{16: 0}$ and iso- $\mathrm{C}_{15: 0}$; mycolic acids are absent. Major menaquinones are tetraand hexahydrogenated with nine isoprene units.

The type strain is $\mathrm{F} 18-98^{\mathrm{T}}\left(=\mathrm{DSM} \quad 44665^{\mathrm{T}}=\mathrm{NCIMB}\right.$ $\left.13932^{\mathrm{T}}\right)$. The organism was isolated from the rhizosphere of Putterlickia verrucosa.

\section{Description of Kitasatospora kifunensis Nakagaito, Shimazu, Yokota and Hasegawa comb. nov.}

Kitasatospora kifunensis (ki.fu.nen'sis. N.L. adj. kifunensis named for Mt Kifune, Kyoto Prefecture, Japan, source of the soil from which the organism was isolated). 
In addition to the properties given in earlier descriptions of this organism (Iwami et al., 1987; Nakagaito et al., 1992a), this species is also characterized by properties acquired in the present study. Aerobic, Gram-positive, non-acid-fast actinomycete that produces melanoid pigments on tyrosine agar, but not on peptone/yeast extract/iron agar or in tryptone/yeast extract broth. Spore-chains are straight, hooked to spiral (rectiflexibiles to spirales). Spores are short, cylindrical and smooth-surfaced $(1 \cdot 2-1 \cdot 3 \times 0 \cdot 6-$ $0 \cdot 7 \mu \mathrm{m})$. Submerged spores are formed sparsely in liquid culture. Temperature range for growth is $10-32^{\circ} \mathrm{C}$; the organism does not grow below $10^{\circ} \mathrm{C}$ or above $32^{\circ} \mathrm{C}$. pH range for growth is 5-9; growth does not occur at $\mathrm{pH} 4.5$ or $9 \cdot 5$. Nitrate is not reduced to nitrite. Gelatin is not liquefied and milk is not peptonized. Casein is degraded. $\mathrm{H}_{2} \mathrm{~S}$ is produced. Starch is hydrolysed. Alkaline phosphatase, esterase (C4), esterase lipase (C8), $\beta$-galactosidase, $\alpha$ glucosidase, leucine arylamidase, naphthol-AS-BI-phosphohydrolase, $\alpha$-mannosidase (weak) and acid phosphatase are produced, but $N$-acetyl- $\beta$-glucosamidase, $\alpha$-chymotrypsin, cystine arylamidase, $\alpha$-fucosidase, $\alpha$-galactosidase, $\beta$-glucosidase, $\beta$-glucuronidase, lipase (C14), trypsin and valine arylamidase are not. $\mathrm{L}(+)$-Arabinose, $\mathrm{D}(+)$-galactose, $\mathrm{D}(+)$-glucose, glycerol, $\mathrm{D}(+)$-maltose, $\mathrm{D}(-)$-mannitol, $\mathrm{D}(+)$-mannose, $\mathrm{D}(-)$-sucrose, $\mathrm{D}(+)$-trehalose and $\mathrm{D}(+)$ xylose are used as sole sources of carbon for energy and growth, but cellulose, chitin, $\mathrm{D}(-)$-fructose, $i$-inositol, inulin, $\mathrm{D}(+)$-lactose, $\mathrm{D}(+)$-raffinose, $\mathrm{L}(+)$-rhamnose and salicin are not. Growth is inhibited by ampicillin $\left(10 \mu \mathrm{g} \mathrm{ml}^{-1}\right.$, weak), chloramphenicol $\left(30 \mu \mathrm{g} \mathrm{ml}^{-1}\right)$, ciprofloxacin $\left(5 \mu \mathrm{g} \mathrm{ml}^{-1}\right)$, imipenem $\left(10 \mu \mathrm{g} \mathrm{ml}^{-1}\right)$, kanamycin sulfate $\left(30 \mu \mathrm{g} \mathrm{ml}^{-1}\right)$, methicillin $\left(5 \mu \mathrm{g} \mathrm{ml}^{-1}\right.$, weak), nalidixic acid $\left(50 \mu \mathrm{g} \mathrm{ml}^{-1}\right)$, novobiocin $\left(2 \cdot 5 \mu \mathrm{g} \mathrm{ml}^{-1}\right)$, oxytetracycline hydrochloride $\left(30 \mu \mathrm{g} \mathrm{ml}^{-1}\right)$, rifampicin $\left(30 \mu \mathrm{g} \mathrm{ml}^{-1}\right)$, streptomycin sulfate $\left(10 \mu \mathrm{g} \mathrm{ml}^{-1}\right)$, sulfonamide $\left(200 \mu \mathrm{g} \mathrm{ml}^{-1}\right.$, weak) and vancomycin hydrochloride $\left(30 \mu \mathrm{g} \mathrm{ml}^{-1}\right)$, but not by lincomycin hydrochloride $\left(2 \mu \mathrm{g} \mathrm{ml}^{-1}\right)$, norfloxacin $\left(10 \mu \mathrm{g} \mathrm{ml}^{-1}\right)$, penicillin $\mathrm{G}(10 \mathrm{IU})$ or polymyxin $\mathrm{B}$ (300 IU). The strain tolerates $2 \cdot 5 \%$, but not $3 \cdot 5 \%, \mathrm{NaCl}$ $(\mathrm{w} / \mathrm{v})$. Resistance is shown to the polyvalent Streptomyces phage S7. Whole-cell chemistry reveals the presence of both meso- and LL- $\mathrm{A}_{2} \mathrm{pm}$; the muramic acid moiety is $\mathrm{N}$ acetylated. Whole-organism hydrolysates contain galactose, mannose, glucose and ribose and the major polar lipids are phosphatidylethanolamine, diphosphatidylglycerol, phosphatidylglycerol, phosphatidylinositol and phosphatidylinositol mannosides. Predominant fatty acids are $\mathrm{C}_{16: 0}$, anteiso- $\mathrm{C}_{15: 0}$ and iso- $\mathrm{C}_{15: 0}$; mycolic acids are absent. Major menaquinone is hexahydrogenated with nine isoprene units.

The type strain is NBRC $15206^{\mathrm{T}}\left(=\mathrm{DSM} 41654^{\mathrm{T}}\right)$. The organism was isolated from a soil sample obtained at $\mathrm{Mt}$ Kifune, Kyoto Prefecture, Japan.

\section{Emended description of Streptomyces aureofaciens Duggar 1948}

Streptomyces aureofaciens (au.re.o.fa'ci.ens. L. adj. aureus golden; L. part. adj. faciens producing; N.L. part. adj. aureofaciens golden-producing, referring to the pigment produced).

In addition to the properties given in descriptions from earlier studies (Duggar, 1948; Shirling \& Gottlieb, 1968; Williams et al., 1983), this species is also characterized by features acquired in the present study. Aerobic, Grampositive, non-acid-fast actinomycete that produces a yellow-brown substrate mycelium and a reddish to grey aerial spore-mass. Does not produce diffusible or melanoid pigments. Spore-chains are flexuous (rectiflexibiles), open loops, hooks or extended spirals (retinaculiaperti) with 10-50 or more cylindrical, smooth-surfaced spores $(1 \cdot 2-2.3 \times 1 \cdot 0-1.5 \mu \mathrm{m})$ per chain. Temperature range for growth is $10-45^{\circ} \mathrm{C}$ (optimum, $28^{\circ} \mathrm{C}$ ). $\mathrm{pH}$ range for growth is 6-9.5; growth does not occur at $\mathrm{pH} 5$ or 10 . Nitrate is not reduced to nitrite. Gelatin is liquefied and milk is peptonized. Casein is degraded and $\mathrm{H}_{2} \mathrm{~S}$ is produced. Starch is hydrolysed. Adenine, elastin, guanine, hypoxanthine, testosterone, Tween 80, L-tyrosine and xanthine are degraded. Aesculin and urea are hydrolysed, but allantoin is not. $N$-Acetyl- $\beta$-glucosamidase, acid phosphatase, alkaline phosphatase, $\alpha$-chymotrypsin, esterase (C4), esterase lipase (C8), $\alpha$-galactosidase, $\beta$-galactosidase, $\alpha$-glucosidase, $\beta$-glucosidase, leucine arylamidase, $\alpha$ mannosidase, naphthol-AS-BI-phosphohydrolase, trypsin and valine arylamidase are produced, but cystine arylamidase, $\alpha$-fucosidase, $\beta$-glucuronidase and lipase (C14) are not. Adonitol (weak), $\mathrm{L}(+)$-arabinose, $\mathrm{D}(+)$-cellobiose, dextran (weak), $\mathrm{D}(-)$-fructose (weak), $\mathrm{D}(+)$-galactose, $\mathrm{D}(+)$-glucose, inulin (weak), $i$-inositol, $\mathrm{D}(+)$-lactose, $\mathrm{D}(+)$-mannose (weak), $\mathrm{D}(-)$-mannitol, $\mathrm{D}(+)$-melibiose, $\mathrm{D}(+)$-melezitose, $\mathrm{D}(+)$-raffinose (weak), $\mathrm{L}(+)$-rhamnose, salicin, $\mathrm{D}(-)$-sucrose, $\mathrm{D}(+)$-trehalose and $\mathrm{D}(+)$-xylose are used as sole sources of carbon for energy and growth, but cellulose, L-histidine and L-phenylalanine are not. Growth is inhibited by chloramphenicol $\left(30 \mu \mathrm{g} \mathrm{ml}^{-1}\right)$, ciprofloxacin $\left(5 \mu \mathrm{g} \mathrm{ml}^{-1}\right)$, imipenem $\left(10 \mu \mathrm{g} \mathrm{ml}^{-1}\right)$, kanamycin sulfate $\left(30 \mu \mathrm{g} \mathrm{ml}^{-1}\right)$, oxytetracycline hydrochloride $\left(30 \mu \mathrm{g} \mathrm{ml}^{-1}\right)$, polymyxin $\mathrm{B}(300 \mathrm{IU})$, rifampicin $\left(30 \mu \mathrm{g} \mathrm{ml}^{-1}\right)$, streptomycin sulfate $\left(10 \mu \mathrm{g} \mathrm{ml}^{-1}\right)$, sulfonamide $\left(200 \mu \mathrm{g} \mathrm{ml}^{-1}\right)$ and vancomycin hydrochloride $\left(30 \mu \mathrm{g} \mathrm{ml}^{-1}\right)$, but not by ampicillin $\left(10 \mu \mathrm{g} \mathrm{ml}^{-1}\right)$, lincomycin hydrochloride $\left(2 \mu \mathrm{g} \mathrm{ml}^{-1}\right)$, methicillin $\left(5 \mu \mathrm{g} \mathrm{ml}^{-1}\right)$, norfloxacin $\left(10 \mu \mathrm{g} \mathrm{ml}^{-1}\right)$ or penicillin $\mathrm{G}(10 \mathrm{IU}) . \mathrm{NaCl}$ is tolerated up to a concentration of $8 \%(\mathrm{w} / \mathrm{v})$. Sensitive to the polyvalent Streptomyces phage S7. Cell wall contains $\mathrm{LL}_{-} \mathrm{A}_{2} \mathrm{pm}$; the muramic acid moiety is $\mathrm{N}$-acetylated. Whole-organism hydrolysates contain ribose, glucose and mannose and major polar lipids are diphosphatidylglycerol, phosphatidylethanolamine and phosphatidylinositol. Predominant fatty acids are anteiso- $\mathrm{C}_{15: 0}, \mathrm{C}_{16: 0}$, iso- $\mathrm{C}_{15: 0}$ and anteiso$\mathrm{C}_{17: 0}$; mycolic acids are absent. The major menaquinones are tetra-, hexa- and octahydrogenated with nine isoprene units.

The type strain is NRRL $2209^{\mathrm{T}}\left(=\mathrm{DSM} 40127^{\mathrm{T}}\right)$. The strain was isolated from timothy field soil, Missouri, USA. 


\section{ACKNOWLEDGEMENTS}

We are grateful to Katrin Buder (Institute of Molecular Biotechnology, Jena) for help with electron microscopy and to Stephanie Lohmann, Renate Schön, Carmen Schult and Christiane Weigel for excellent technical assistance. C. R. was supported by a studentship from the Ecuadorian FUNDACYT (Foundation for Science and Technology) and by an Overseas Research Scholarship Award. We acknowledge support by grants from the Deutsche Forschungsgemeinschaft (Le260/ 15-1 and /15-2), Fonds der Chemischen Industrie (to E. L.) and the Cusanus Werk (to C. B.P.). M.G. is also grateful for support from the European Commission (grant QLK3-CT-2001-01783).

\section{REFERENCES}

Becker, B., Lechevalier, M. P. \& Lechevalier, H. A. (1965). Chemical composition of cell-wall preparation from strains of various formgenera of aerobic actinomycetes. Appl Microbiol 13, 236-243.

Bouchek-Mechiche, K., Gardan, L., Normand, P. \& Jouan, B. (2000). DNA relatedness among strains of Streptomyces pathogenic to potato in France: description of three new species, S. europaeiscabiei sp. nov. and $S$. stelliscabiei sp. nov. associated with common scab, and $S$. reticuliscabiei sp. nov. associated with netted scab. Int J Syst Evol Microbiol 50, 91-99.

Chun, J. (1995). Computer-assisted classification and identification of actinomycetes. $\mathrm{PhD}$ thesis, University of Newcastle, Newcastle upon Tyne, UK.

Chung, Y. R., Sung, K. C., Mo, H. K., Son, D. Y., Nam, J. S., Chun, J. \& Bae, K. S. (1999). Kitasatospora cheerisanensis sp. nov., a new species of the genus Kitasatospora that produces an antifungal agent. Int J Syst Bacteriol 49, 753-758.

Collins, M. D. \& Jones, D. (1980). Lipids in the classification and identification of coryneform bacteria containing peptidoglycans based on 2,4-diaminobutyric acid. J Appl Bacteriol 48, 459-470.

Collins, M. D., Pirouz, T., Goodfellow, M. \& Minnikin, D. E. (1977). Distribution of menaquinones in actinomycetes and corynebacteria. J Gen Microbiol 100, 221-230.

Cowan, S. T. \& Steel, K. J. (1965). Manual for the Identification of Medical Bacteria. London: Cambridge University Press.

Duggar, B. M. (1948). Aureomycin: a product of the continuing search for new antibiotics. Ann N Y Acad Sci 51, 177-181.

Edwards, U., Rogall, T., Blöcker, H., Emde, M. \& Böttger, E. C. (1989). Isolation and direct complete nucleotide determination of entire genes. Characterization of a gene coding for $16 \mathrm{~S}$ ribosomal RNA. Nucleic Acids Res 17, 7843-7853.

Felsenstein, J. (1981). Evolutionary trees from DNA sequences: a maximum likelihood approach. J Mol Evol 17, 368-376.

Felsenstein, J. (1985). Confidence limits on phylogenies: an approach using the bootstrap. Evolution 39, 783-791.

Felsenstein, J. (1993). PHYLIP (phylogeny inference package), version 3.5c. Department of Genetics, University of Washington, Seattle, USA.

Fitch, W. M. \& Margoliash, E. (1967). Construction of phylogenetic trees. Science 155, 279-284.

Goyer, C., Faucher, E. \& Beaulieu, C. (1996). Streptomyces caviscabies sp. nov., from deep-pitted lesions in potatoes in Québec, Canada. Int J Syst Bacteriol 46, 635-639.

Hasegawa, T., Takizawa, M. \& Tanida, S. (1983). A rapid analysis for chemical grouping of aerobic actinomycetes. J Gen Appl Microbiol 329, 319-322.
Hunter-Cevera, J. C., Fonda, M. E. \& Belt, A. (1986). Isolation of cultures. In Manual of Industrial Microbiology and Biotechnology, pp. 3-23. Edited by A. L. Demain \& N. A. Solomon. Washington, DC: American Society for Microbiology.

Iwami, M., Nakayama, O., Terano, H., Kohsaka, M., Aoki, H. \& Imanaka, H. (1987). A new immunomodulator, FR-900494: taxonomy, fermentation, isolation, and physico-chemical and biological characteristics. J Antibiot (Tokyo) 40, 612-622.

Jukes, T. H. \& Cantor, C. R. (1969). Evolution of protein molecules. In Mammalian Protein Metabolism, pp. 21-132. Edited by H. N. Munro. New York: Academic Press.

Kim, S. B. \& Goodfellow, M. (2002). Streptomyces thermospinisporus sp. nov., a moderately thermophilic carboxydotrophic streptomycete isolated from soil. Int J Syst Evol Microbiol 52, 1225-1228.

Kim, S. B., Falconer, C., Williams, E. \& Goodfellow, M. (1998). Streptomyces thermocarboxydovorans $\mathrm{sp}$. nov. and Streptomyces thermocarboxydus sp. nov., two moderately thermophilic carboxydotrophic species from soil. Int J Syst Bacteriol 48, 58-68.

Kim, S. B., Lonsdale, J., Seong, C. N. \& Goodfellow, M. (2003). Streptacidiphilus gen. nov., acidophilic actinomycetes with wall chemotype I and emendation of the family Streptomycetaceae (Waksman and Henrici $(1943)^{\mathrm{AL}}$ ) emend. Rainey et al. 1997. Antonie van Leeuwenhoek 83, 107-116.

Kreuze, J. F., Suomalainen, S., Paulin, L. \& Valkonen, J. P. T. (1999). Phylogenetic analysis of 16S rRNA genes and PCR analysis of the necl gene from Streptomyces spp. causing common scab, pitted scab, and netted scab in Finland. Phytopathology 89, 462-469.

Kusakabe, H. \& Isono, K. (1992). Kitasatosporia cystarginea sp. nov. In Validation of the Publication of New Names and New Combinations Previously Effectively Published Outside the IJSB, List no. 41. Int J Syst Bacteriol 42, 327-328.

Labeda, D. P. (1988). Kitasatosporia mediocidica sp. nov. Int J Syst Bacteriol 38, 287-290.

Labeda, D. P. (1993). DNA relatedness among strains of the Streptomyces lavendulae phenotypic cluster group. Int J Syst Bacteriol 43, 822-825.

Labeda, D. P. (1998). DNA relatedness among the Streptomyces fulvissimus and Streptomyces griseoviridis phenotypic cluster groups. Int J Syst Bacteriol 48, 829-832.

Labeda, D. P. \& Lyons, A. J. (1992). DNA relatedness among strains of the sweet potato pathogen Streptomyces ipomoea (Person and Martin 1940) Waksman and Henrici 1948. Appl Environ Microbiol 58, 532-535.

Lányi, B. (1987). Classical and rapid identification methods for medically important bacteria. Methods Microbiol 19, 1-67.

Lechevalier, M. P., De Bièvre, C. \& Lechevalier, H. A. (1977). Chemotaxonomy of aerobic actinomycetes: phospholipid composition. Biochem Syst Ecol 5, 249-260.

Manfio, G. P., Zakrzewska-Czerwinska, J., Atalan, E. \& Goodfellow, M. (1995). Towards minimal standards for the description of Streptomyces species. Biotekhnologiya 7-8, 242-253.

Minnikin, D. E., Alshamaony, L. \& Goodfellow, M. (1975). Differentiation of Mycobacterium, Nocardia, and related taxa by thin-layer chromatographic analysis of whole-organism methanolysates. J Gen Microbiol 88, 200-204.

Minnikin, D. E., Collins, M. D. \& Goodfellow, M. (1979). Fatty acid and polar lipid composition in the classification of Cellulomonas, Oerskovia and related taxa. J Appl Bacteriol 47, 87-95.

Nakagaito, Y., Shimazu, A., Yokota, A. \& Hasegawa, T. (1992a). Proposal of Streptomyces atroaurantiacus sp. nov. and Streptomyces kifunensis sp. nov. and transferring Kitasatosporia cystarginea 
Kusakabe and Isono to the genus Streptomyces as Streptomyces cystargineus comb. nov. J Gen Appl Microbiol 38, 627-633.

Nakagaito, Y., Yokota, A. \& Hasegawa, T. (1992b). Three new species of the genus Streptomyces: Streptomyces cochleatus sp. nov., Streptomyces paracochleatus sp. nov., and Streptomyces azaticus sp. nov. J Gen Appl Microbiol 38, 105-120.

Nakagaito, Y., Shimazu, A., Yokota, A. \& Hasegawa, T. (1993). Streptomyces atroaurantiacus sp. nov., Streptomyces cystargineus comb. nov. and Streptomyces kifunensis sp. nov. In Validation of the Publication of New Names and New Combinations Previously Effectively Published Outside the IJSB, List no. 46. Int J Syst Bacteriol 43, 624.

Ochi, K. \& Hiranuma, H. (1994). A taxonomic review of the genera Kitasatosporia and Streptoverticillium by analysis of ribosomal protein AT-L30. Int J Syst Bacteriol 44, 285-292.

Ōmura, S., Iwai, Y., Takahashi, Y., Kojima, K., Otoguro, K. \& Oiwa, R. (1981). Type of diaminopimelic acid different in aerial and vegetative mycelia of setamycin-producing actinomycete KM-6054. J Antibiot (Tokyo) 34, 1633-1634.

Ōmura, S., Takahashi, Y., Iwai, Y. \& Tanaka, H. (1982). Kitasatosporia, a new genus of the order Actinomycetales. J Antibiot (Tokyo) 35, 1013-1019.

Ōmura, S., Takahashi, Y., Iwai, Y. \& Tanaka, H. (1983). Kitasatosporia setalba sp. nov. In Validation of the Publication of New Names and New Combinations Previously Effectively Published Outside the IJSB, List no. 11. Int J Syst Bacteriol 33, 672-674.

Ōmura, S., Takahashi, Y., Iwai, Y. \& Tanaka, H. (1985). Revised nomenclature of Kitasatosporia setalba. Int J Syst Bacteriol 35, 221.

Prauser, H., Schütze, B. \& Martin, D. (editors) (1987). IMET (National Collection of Microorganisms) Catalogue of Strains. Jena, Germany: ZIMET.

Pullen, C., Schmitz, P., Meurer, K. \& 9 other authors (2002). New and bioactive compounds from Streptomyces strains residing in the wood of Celastraceae. Planta 216, 162-167.

Pullen, C. B., Schmitz, P., Hoffmann, D. \& 11 other authors (2003). Occurrence and non-detectability of maytansinoids in individual plants of the genera Maytenus and Putterlickia. Phytochemistry 62, 377-387.

Rhuland, L. E., Work, E., Denman, R. F. \& Hoare, D. S. (1955). The behavior of the isomers of $\alpha, \varepsilon$-diaminopimelic acid on paper chromatograms. J Am Chem Soc 77, 4844-4846.

Saddler, G. S., Tavecchia, P., Lociuro, S., Zanol, M., Colombo, L. \& Selva, E. (1991). Analysis of madurose and other actinomycete whole cell sugars by gas chromatography. J Microbiol Methods 14, 185-191.

Saitou, N. \& Nei, M. (1987). The neighbor-joining method: A new method for reconstructing phylogenetic trees. Mol Biol Evol 4, 406-425.
Sembiring, L., Ward, A. C. \& Goodfellow, M. (2000). Selective isolation and characterisation of members of the Streptomyces violaceusniger clade associated with the roots of Paraserianthes falcataria. Antonie van Leeuwenhoek 78, 353-366.

Shirling, E. B. \& Gottlieb, D. (1966). Methods for characterization of Streptomyces species. Int J Syst Bacteriol 16, 313-340.

Shirling, E. B. \& Gottlieb, D. (1968). Cooperative description of type cultures of Streptomyces. III. Additional species descriptions from first and second studies. Int J Syst Bacteriol 18, 279-392.

Tajima, K., Takahashi, Y., Seino, A., Iwai, Y. \& Ōmura, S. (2001). Description of two novel species of the genus Kitasatospora Ōmura et al. 1982, Kitasatospora cineracea sp. nov. and Kitasatospora niigatensis sp. nov. Int J Syst Evol Microbiol 51, 1765-1771.

Takahashi, Y., Kuwana, T., Iwai, Y. \& Ōmura, S. (1984). Some characteristics of aerial and submerged spores of Kitasatosporia setalba. J Gen Appl Microbiol 30, 223-229.

Takahashi, Y., Iwai, Y. \& Ōmura, S. (1985). Kitasatosporia griseola sp. nov. In Validation of the Publication of New Names and New Combinations Previously Effectively Published Outside the IJSB, List no. 19. Int J Syst Bacteriol 35, 535.

Uchida, K. \& Aida, K. (1984). An improved method for the glycolate test for simple identification of the acyl type of bacterial cell walls. J Gen Appl Microbiol 30, 131-134.

Wang, Y., Zhang, Z. \& Ruan, J. (1996a). Phylogenetic analysis reveals new relationships among members of the genera Microtetraspora and Microbispora. Int J Syst Bacteriol 46, 658-663.

Wang, Y., Zhang, Z. \& Ruan, J. (1996b). A proposal to transfer Microbispora bispora (Lechevalier 1965) to a new genus, Thermobispora gen. nov., as Thermobispora bispora comb. nov. Int J Syst Bacteriol 46, 933-938.

Wellington, E. M. H., Stackebrandt, E., Sanders, D., Wolstrup, J. \& Jorgensen, N. O. G. (1992). Taxonomic status of Kitasatosporia, and proposed unification with Streptomyces on the basis of phenotypic and 16S rRNA analysis and emendation of Streptomyces Waksman and Henrici 1943, 339 $9^{\mathrm{AL}}$. Int J Syst Bacteriol 42, 156-160.

Williams, S. T., Goodfellow, M., Alderson, G., Wellington, E. M. H., Sneath, P. H. A. \& Sackin, M. J. (1983). Numerical classification of Streptomyces and related genera. J Gen Microbiol 129, 17431813.

Williams, S. T., Goodfellow, M. \& Alderson, G. (1989). Genus Streptomyces Waksman and Henrici 1943, 339 ${ }^{\mathrm{AL}}$. In Bergey's Manual of Systematic Bacteriology, vol. 4, pp. 2452-492. Edited by S. T. Williams, M. E. Sharpe and J. G. Holt. Baltimore: Williams \& Wilkins.

Zhang, Z., Wang, Y. \& Ruan, J. (1997). A proposal to revive the genus Kitasatospora (Ōmura, Takahashi, Iwai, and Tanaka 1982). Int J Syst Bacteriol 47, 1048-1054. 